\title{
Assessment of fermentation in growing pigs given unmolassed sugar-beet pulp: a stoichiometric approach
}

\author{
BY J. Q. ZHU*, V. R. FOWLER† AND M. F. FULLER \\ Rowett Research Institute, Bucksburn, Aberdeen AB29SB
}

(Received 4 November 1991-Accepted 25 March 1992)

\begin{abstract}
In four experiments growing pigs were given a cereal-based diet alone or supplemented with unmolassed sugar-beet pulp (SBP), used as a model substrate for fermentation. The rates of production of methane and gaseous hydrogen were measured and, together with the molar proportions of volatile fatty acids (VFA) in the digesta, used in stoichiometric calculations of fermentation. The resulting estimates were only one-sixth of the observed extent of digestion of SBP. Bacteriostatic levels of antibiotics reduced fermentation by more than half, as judged from the digestion of non-starch polysaccharides: allowing for the incomplete suppression of fermentation it was estimated that the production of methane and VFA could account completely for the digested SBP. The potential contribution of various routes of hydrogen disposal to the error of the stoichiometric calculations is discussed.
\end{abstract}

Fermentation: Unmolassed sugar-beet pulp: Pig

The importance of hind-gut fermentation in the nutrition of the pig has been well recognized, especially when diets include large proportions of fermentable fibrous materials. The digestible energy (DE) which can be supplied from gut fermentation can exceed $30 \%$ of total dietary DE (Just et al. 1983a, b; Rérat et al. 1987). It has been suggested that the microbial ecosystem of the hind-gut of the pig closely resembles that of the rumen (Bayley, 1978; Rérat, 1978; Wolin, 1981). The end-products of fermentation in the hind-gut and the rumen are similar in that complex carbohydrates, proteins and fatty acids are degraded by micro-organisms to volatile fatty acids (mainly acetic, propionic and butyric acids), combustible gases (methane and hydrogen), water, carbon dioxide and microbial mass. In addition, fermentation heat is evolved and small quantities of succinate, formate, hydrogen sulphide and ammonia are also produced. The biochemical pathways of the two ecosystems are virtually the same (Wolin, 1974, 1981; Mason, 1983).

Based on the stoichiometry of the known biochemical processes, Wolin (1960) suggested that the extent of microbial fermentation in the rumen can be calculated from information on VFA molar proportions and methane production. This approach was further elaborated by Hungate (1966) and Ørskov et al. (1968), and was used by Whitelaw et al. (1970). The stoichiometric calculations are based on the following biochemical pathways.

$$
\begin{aligned}
& \mathrm{C}_{6} \mathrm{H}_{12} \mathrm{O}_{6}+2 \mathrm{H}_{2} \mathrm{O} \rightarrow 2 \mathrm{CH}_{3} \mathrm{COOH}+2 \mathrm{CO}_{2}+4 \mathrm{H}_{2} \\
& \mathrm{C}_{6} \mathrm{H}_{12} \mathrm{O}_{6}+2 \mathrm{H}_{2} \rightarrow 2 \mathrm{CH}_{3} \mathrm{CH}_{2} \mathrm{COOH}+2 \mathrm{H}_{2} \mathrm{O} \\
& \mathrm{C}_{6} \mathrm{H}_{12} \mathrm{O}_{6} \rightarrow \mathrm{CH}_{3} \mathrm{CH}_{2} \mathrm{CH}_{2} \mathrm{COOH}+2 \mathrm{CO}_{2}+2 \mathrm{H}_{2} \\
& 4 \mathrm{H}_{2}+\mathrm{CO}_{2} \rightarrow \mathrm{CH}_{4}+2 \mathrm{H}_{2} \mathrm{O}
\end{aligned}
$$

* Present address: Continental Grain Co., Room 801, Asia Pacific Building 8, Ya Bao Road, Chao Yang, Beijing 100020, China.

$\dagger$ Present address: Scottish Agricultural College, King Street, Aberdeen AB9 IUD.

† For reprints. 
Theoretically, this approach can be used to estimate the production of VFA and total fermented energy (measured as hexose) provided that methane production and the molar proportions of acetic, propionic and butyric acids are known. Estimates made by this approach appear to accord with those made by direct experiment (Wolin, 1960; Ørskov et al. 1968).

The present report describes four experiments, all using unmolassed sugar-beet pulp (SBP) as the model fermentable substrate. Additionally observations were made of the proportions of VFA in the large intestine digesta of pigs given the control diet alone or supplemented with SBP. In Expts 1 and 2 the production of methane and of gaseous hydrogen resulting from the fermentation of SBP was measured. These results were used in conjunction with data on the molar proportions of VFA determined in a separate experiment with the same diets (Zhu et al. 1990) to calculate the production of VFA.

In the third experiment, microbial fermentation was suppressed using bacteriostatic levels of a mixture of antibiotics. The energy digested was compared in pigs with and without antibiotics to give an estimate of the energy digested exclusively by microbial fermentation. Subsequently, this estimate of the total digested energy from fermentation was used together with the VFA molar proportions to calculate the quantities of methane expected during the fermentation of SBP.

The last experiment was to test whether combustible gases from fermentation were still produced when large doses of antibiotics were applied. The results of these experiments were used to estimate the validity of stoichiometric approaches to estimating the extent of fermentation in non-ruminant animals.

\section{MATERIALS AND METHODS}

Animals

In all experiments female Large White $\times($ Landrace $\times$ Large White) pigs were used. Eight pigs of $51 \mathrm{~kg}$, four pigs of $44 \mathrm{~kg}$, eight pigs of $47 \mathrm{~kg}$ and two pigs of $48 \mathrm{~kg}$ respectively were used in the four experiments. In addition to these four experiments, digesta were collected at slaughter from eight of the pigs in the experiment reported by Zhu et al. (1990) for the determination of VFA proportions.

\section{Diets and feeding}

The same diets were used in all experiments, a cereal-based control diet $(\mathrm{C})$ and diet $\mathrm{C}$ supplemented with $300 \mathrm{~g} \mathrm{SBP} / \mathrm{kg}$. The same batch of unmolassed SBP was used as in the experiments previously reported (Zhu et al. 1990) and its chemical analysis is given in Table 1. The composition and chemical analysis of the diets are also given in Table 1. In Expt 3, Cr-mordanted fibre (Uden et al. 1980), using SBP, was incorporated into the two diets at a level of $10 \mathrm{~g} / \mathrm{kg}$ as a marker for estimating digestibility.

The feed intakes $(\mathrm{kg} / \mathrm{d})$ for the four experiments were as follows:

$$
\text { Expt Diet C Diet SBP }
$$

$\begin{array}{lll}1 & 1.27 & 1.64 \\ 2 & 1.15 & 1.50 \\ 3 & 1.20 & 1.60 \\ 4 & 1.20 & 1.60\end{array}$

Pigs were fed twice daily ( 08.00 hours and 16.00 hours) with 3 litres water. Spillages were collected and added to the next meal. 
Table 1. Composition and chemical analysis of the experimental diets $(\mathrm{g} / \mathrm{kg})$

\begin{tabular}{|c|c|c|}
\hline Constituent & Control & SBP \\
\hline Barley & $351 \cdot 9$ & $246 \cdot 3$ \\
\hline Wheat & $351 \cdot 8$ & $246 \cdot 3$ \\
\hline White fish meal & $123 \cdot 1$ & $88 \cdot 2$ \\
\hline Soya-bean meal & $160 \cdot 0$ & $112 \cdot 0$ \\
\hline Lysine hydrochloride & $2 \cdot 5$ & 1.7 \\
\hline Vitamins/minerals* & $2 \cdot 5$ & 1.7 \\
\hline Dicalcium phosphate & $6 \cdot 1$ & $4 \cdot 4$ \\
\hline Salt & $2 \cdot 1$ & $1 \cdot 4$ \\
\hline Unmolassed sugar-beet pulp (SBP) $\dagger$ & 0 & $300 \cdot 0$ \\
\hline \multicolumn{3}{|l|}{ Chemical analysis } \\
\hline Dry matter $(\mathrm{g} / \mathrm{kg})$ & 882 & 895 \\
\hline Crude protein $(\mathrm{N} \times 6.25 ; \mathrm{g} / \mathrm{kg})$ & 245 & 200 \\
\hline Gross energy $(\mathrm{MJ} / \mathrm{kg})$ & $15 \cdot 5$ & $15 \cdot 5$ \\
\hline $\mathrm{NDF}(\mathrm{g} / \mathrm{kg})$ & 119 & 206 \\
\hline
\end{tabular}

NDF, neutral detergent fibre.

* Vitamins (per $1000 \mathrm{~kg}$ ): retinyl acetate and retinyl palmitate (equivalent to retinol) $1.5 \mathrm{~g}$, cholecalciferol $25 \mathrm{mg}, \alpha$-tocopherol acetate $5 \mathrm{~g}$, phylloquinone $1 \mathrm{~g}$, riboflavin $4.5 \mathrm{~g}$, cyanocobolamin $11 \mathrm{mg}$, pantothenic acid $12 \mathrm{~g}$, nicotinic acid $19 \mathrm{~g}$. Minerals (g/kg): Fe 80, Zn 100, Mn 40, Mg 420, Cu 150, I 2, Co 0.5, Se 0.15.

$\dagger$ Containing ( $\mathrm{g} / \mathrm{kg}$, air-dry basis) dry matter 932 , crude protein 105 , crude fat 8 , non-starch polysaccharides 607 , NDF 410, soluble sucrose 71 , lignin 21 , ash 84 .

\section{VFA molar proportions}

Digesta were taken from the large intestines of eight pigs in the experiment previously reported (Zhu et al. 1990), four given diet C and four given diet SBP. The molar proportions of acetic, propionic and butyric acids were measured by GLC. These proportions were used for stoichiometric calculations.

\section{Treatments and experimental design}

In each of the first two experiments there were two treatments corresponding to the two diets. The design in each was a $2 \times 2$ Latin square with two pigs and two periods; in the first experiment there were four replicates and in the second, two. In Expt 3 there were four treatments, consisting of two diets each given first without and then with antibiotics. Two animals were allocated to each diet; thus, diets were compared between pigs, whereas the effects of antibiotics were assessed within animals. In the fourth experiment there were two diets, with one animal given each. In each experiment involving a change of diet an adaptation period of $7 \mathrm{~d}$ was allowed during which the pigs were given the diet they would receive in the next period.

\section{Experimental procedures}

In Expt 1 two open-circuit chambers were used. Both chambers were maintained at $20^{\circ}$ and air flow-rates were adjusted to about $5 \mathrm{l} / \mathrm{h}$. The chambers were calibrated and methane recovery was about $98 \%$. In Expts 2 and 4 closed-circuit chambers were used (Brockway et al. 1977). These chambers were also maintained at $20^{\circ}$. In Expt 3 the pigs were kept in metabolism cages in a room maintained at $20^{\circ}$.

The experimental periods lasted for $7 \mathrm{~d}$. In all experiments pigs were accustomed to metabolism cages for $7 \mathrm{~d}$ except that in Expt 4 the pigs had a preliminary period of only 
$4 \mathrm{~d}$ followed by a $7 \mathrm{~d}$ experimental period. In Expts 1, 2 and 4 urine was collected into plastic bins containing $50 \mathrm{ml} 1 \mathrm{M}-\mathrm{H}_{2} \mathrm{SO}_{4}$. In the third experiment pigs had bladder catheters (14 gauge). Faeces were also collected into $\mathrm{H}_{2} \mathrm{SO}_{4}$, the level being maintained to keep the faeces covered.

Gas sampling and analytical methods. In Expt 1 the daily methane production was measured over the last $3 \mathrm{~d}$ of each period. Methane was determined by Infra-red Analyser (Analytical Development Co. Ltd, Hoddesdon, Herts). The concentrations of methane and hydrogen were determined in gas samples taken at the beginning and the end of a $24 \mathrm{~h}$ period. The rates of production were calculated from the difference between the initial and final volumes of hydrogen and methane. The relative concentrations of hydrogen and methane were estimated by GLC.

Antibiotics. The antibiotics used in Expts 3 and 4 were Zinc Bacitracin (Sigma) and Neomycin Sulphate (Sigma). Both were included in diet $\mathrm{C}$ at $1.7 \mathrm{~g} / \mathrm{kg}$ on the first day of treatment and $1.2 \mathrm{~g} / \mathrm{kg}$ thereafter, and in diet SBP at $2.5 \mathrm{~g} / \mathrm{kg}$ on day 1 and $1.9 \mathrm{~g} / \mathrm{kg}$ on each subsequent day. In addition, Clamoxyl (Wellington) was included in diet Cat $8.7 \mathrm{~g} / \mathrm{kg}$ on day 1 , then at $5.9 \mathrm{~g} / \mathrm{kg}$; in diet SBP the inclusions were $11.2 \mathrm{~g} / \mathrm{kg}$ on day 1 , then $8.5 \mathrm{~g} / \mathrm{kg}$.

Faeces and urine collections. In Expt 3 faeces and urine were collected separately for the last $3 \mathrm{~d}$ in each period. At $1 \mathrm{~d}$ before the collection, urinary catheters (14 gauge) were introduced into the bladder. At $1 \mathrm{~d}$ before the introduction of the catheter pigs were injected intramuscularly with long-acting Clamoxyl $(2 \mathrm{ml})$ to prevent urinary tract infection. The urine was collected into approximately $50 \mathrm{ml} 1 \mathrm{M}-\mathrm{H}_{2} \mathrm{SO}_{4}$. Faeces were collected daily and stored at $-20^{\circ}$.

Chemical analyses. Chemical analyses were carried out on ground faecal samples; dry matter (Association of Official Analytical Chemists, 1965), energy (using an adiabatic bomb calorimeter), nitrogen (Davidson et al. 1970), soluble sugars (by HPLC), starch (Åman \& Hesselman, 1984), lignin (Christian, 1971) and non-starch polysaccharides (NSP) (Englyst, 1981) as well as Cr (Matheson, 1970).

\section{Statistics}

The results were analysed by analysis of variance using GENSTAT (Lawes Agricultural Trust, 1984). In Expts 1 and 2 the diets were treated as the only treatment factor. Periods and individual pigs were included as the block factors. In Expt 3 the same statistical analysis was performed with individual pigs as blocking factors. Treatment factors included diets and antibiotics.

\section{RESULTS}

$V F A$ molar proportions. The molar proportions of acetic, propionic and butyric acids measured in the digesta at slaughter from the large intestine of pigs receiving these two diets are summarized in Table 2. The difference between the two treatments was not significant.

Expt 1. The measured production of methane together with the stoichiometrically calculated values for the production of VFA, heat produced during the fermentation and energy digested via microbial action are summarized in Table 3. The assessment of the rates of VFA production and fermented energy resulting from the fermentation of SBP involved the assumption that there were no associative effects between the control diet and the added SBP, specifically that the rates of VFA production were the same when it was given with SBP as when it was given alone. Allowance was also made for the unequal intakes of diet $C$. 
Table 2. Molar proportions of volatile fatty acids in the digesta of the large intestine of growing pigs given a cereal-based diet alone or supplemented with $300 \mathrm{~g}$ unmolassed sugarbeet pulp $(S B P) / \mathrm{kg}$

(Mean values for four observations per treatment)

\begin{tabular}{lccc}
\hline Treatment* & Acetate & Propionate & Butyrate \\
Control & 0.59 & $0 \cdot 24$ & $0 \cdot 17$ \\
SBP & 0.59 & $0 \cdot 23$ & $0 \cdot 18$ \\
Statistical significance of difference & $\mathrm{NS}$ & $\mathrm{NS}$ & $\mathrm{NS}$ \\
SED $(3 \mathrm{df})$ & 0.0166 & 0.0216 & $0 \cdot 0187$ \\
\hline
\end{tabular}

NS, not significant; SED, standard error of difference.

* For details, see pp. 512-513 and Table 1.

Table 3. Expt 1. Measured methane production and stoichiometrically estimated values of volatile fatty acid production and fermented energy of growing pigs given a cereal-based diet alone $(C)$ or supplemented with $300 \mathrm{~g}$ unmolassed sugar-beet pulp $(S B P) / \mathrm{kg}^{*}$

\begin{tabular}{|c|c|c|c|c|c|}
\hline & \multirow[b]{2}{*}{ Diet $\mathrm{C}$} & \multirow[b]{2}{*}{ Diet SBP } & \multirow[b]{2}{*}{ SBP supplement } & \multicolumn{2}{|c|}{ Difference between diets } \\
\hline & & & & $\begin{array}{l}\text { SED } \\
(11 \mathrm{df})\end{array}$ & $\begin{array}{c}\text { Statistical } \\
\text { significance } \\
\text { of difference: } P<\end{array}$ \\
\hline Methane† (l/d) & $2 \cdot 27$ & $5-36$ & $3 \cdot 30$ & $0 \cdot 410$ & $0 \cdot 01$ \\
\hline Acetate $(\mathrm{MJ} / \mathrm{d})$ & $0 \cdot 165$ & $0-379$ & $0 \cdot 229$ & $0 \cdot 028$ & 0.01 \\
\hline Propionate $(\mathrm{MJ} / \mathrm{d})$ & $0 \cdot 118$ & 0.259 & $0 \cdot 151$ & $0 \cdot 019$ & 0.01 \\
\hline Butyrate $(\mathrm{MJ} / \mathrm{d})$ & $0 \cdot 119$ & $0 \cdot 290$ & $0 \cdot 151$ & $0 \cdot 022$ & $0 \cdot 01$ \\
\hline Fermented energy $(\mathrm{MJ} / \mathrm{d})$ & 0.525 & $1 \cdot 217$ & 0.740 & $0 \cdot 093$ & 001 \\
\hline DE intake+ $(\mathrm{MJ} / \mathrm{d})$ & $16 \cdot 74$ & $19-83$ & $4 \cdot 70$ & & \\
\hline Methane/DE (\%) & $0 \cdot 540$ & $1 \cdot 08$ & $2 \cdot 81$ & $0 \cdot 079$ & 0.01 \\
\hline VFA/DE $(\%)$ & $2 \cdot 40$ & $4 \cdot 68$ & $11 \cdot 3$ & $0 \cdot 34$ & 0.01 \\
\hline Fermented energy/DE (\%) & $3 \cdot 14$ & $6 \cdot 14$ & $15 \cdot 8$ & $0 \cdot 448$ & 0.01 \\
\hline
\end{tabular}

SED, standard error of difference; DE, digestible energy.

* For details of treatments, see pp. 513-514 and Table 1.

$\dagger$ Energy value of methane $0.04 \mathrm{MJ} / \mathrm{l}$.

\$DE 13.18 and $12.09 \mathrm{MJ} / \mathrm{kg}$ for diets C and SBP respectively; DE of SBP $9.56 \mathrm{MJ} / \mathrm{kg}$ (Zhu et al. 1990).

From Table 3 it can be seen that diet SBP gave a significantly higher production of methane than diet 6 . However, the estimate of fermented energy by stoichiometric calculation was only $15.8 \%$ of the measured digested energy. This implies either that $84.2 \%$ of the digested energy was derived from endogenous enzymic hydrolysis rather than from microbial action or that the stoichiometric estimate is in error. Since most of the constituents of SBP can only be digested via microbial fermentation it seemed possible that one source of error in the stoichiometric calculation might arise by the production of hydrogen in the free form, which is often substantial in similar studies carried out on humans (Levitt, 1969; Levitt \& Donaldson, 1970; Levitt et al. 1981; Marthinsen \& Fleming, 1982).

Expt 2. Results are summarized in Table 4. The production of gaseous hydrogen was 
Table 4. Expt 2. Measured hydrogen and methane production and stoichiometrically estimated values of volatile fatty acid production and fermented energy of growing pigs given a cereal-based diet alone $(C)$ or supplemented with $300 \mathrm{~g}$ unmolassed sugar-beet pulp $(S B P) / k^{*} *$

\begin{tabular}{|c|c|c|c|c|c|}
\hline & \multirow[b]{2}{*}{ Diet C } & \multirow[b]{2}{*}{ Diet SBP } & \multirow[b]{2}{*}{ SBP supplement } & \multicolumn{2}{|c|}{ Difference between diets } \\
\hline & & & & $\begin{array}{l}\text { SED } \\
(3 \mathrm{df})\end{array}$ & $\begin{array}{c}\text { Statistical } \\
\text { significance } \\
\text { of difference : } P<\end{array}$ \\
\hline $\begin{array}{l}\text { Hydrogen }(1 / d) \\
\text { Methane }(1 / d)\end{array}$ & $\begin{array}{l}1.01 \\
2.35\end{array}$ & $\begin{array}{l}2 \cdot 13 \\
5 \cdot 13\end{array}$ & $\begin{array}{l}1 \cdot 21 \\
2 \cdot 99\end{array}$ & $\begin{array}{l}0.303 \\
0.547\end{array}$ & $\begin{array}{l}0.01 \\
0.01\end{array}$ \\
\hline $\begin{array}{l}\text { Acetate }(\mathrm{MJ} / \mathrm{d}) \\
\text { Propionate }(\mathrm{MJ} / \mathrm{d}) \\
\text { Butyrate }(\mathrm{MJ} / \mathrm{d}) \\
\text { Fermented energy }(\mathrm{MJ} / \mathrm{d})\end{array}$ & $\begin{array}{l}0 \cdot 169 \\
0 \cdot 121 \\
0 \cdot 122 \\
0 \cdot 537\end{array}$ & $\begin{array}{l}0 \cdot 362 \\
0.248 \\
0.277 \\
1.164\end{array}$ & $\begin{array}{l}0.208 \\
0 \cdot 138 \\
0 \cdot 166 \\
0.676\end{array}$ & $\begin{array}{l}0.038 \\
0.026 \\
0.030 \\
0.124\end{array}$ & $\begin{array}{l}0.01 \\
0.01 \\
0.01 \\
0.01\end{array}$ \\
\hline $\mathrm{DE}$ intake $\dagger(\mathrm{MJ} / \mathrm{d})$ & $15 \cdot 16$ & $18 \cdot 14$ & $4 \cdot 30$ & & \\
\hline $\begin{array}{l}\text { Methane/DE }(\%) \\
\text { VFA/DE }(\%) \\
\text { Fermented energy/DE }(\%)\end{array}$ & $\begin{array}{l}0 \cdot 620 \\
2 \cdot 72 \\
3 \cdot 54\end{array}$ & $\begin{array}{l}1 \cdot 13 \\
4 \cdot 89 \\
6 \cdot 42\end{array}$ & $\begin{array}{c}2 \cdot 78 \\
11.9 \\
15.7\end{array}$ & $\begin{array}{l}0.121 \\
0.528 \\
0.689\end{array}$ & $\begin{array}{l}0 \cdot 01 \\
0 \cdot 01 \\
0 \cdot 01\end{array}$ \\
\hline
\end{tabular}

SED, standard error of difference; DE, digestible energy.

* For details of treatments, see pp. 513-514 and Table 1.

$\uparrow$ The DE values of the two diets are those determined in Expt 3.

small. Because the formation of 1 mol methane needs 4 mol hydrogen the inclusion of hydrogen in the stoichiometric calculation did not significantly affect the estimate of fermentation.

The results were comparable with those of Expt 1 in that the SBP resulted in a significantly higher production of methane and gaseous hydrogen than the control treatment. Moreover, the fermented energy of the increment of SBP calculated stoichiometrically was again only $15 \cdot 7 \%$ of its digested energy, in close agreement with the results of the first experiment.

Expt 3. The addition of antibiotics resulted in greater faecal bulk, but whereas with diet $C$ the effect was small, with diet SBP faecal bulk increased from 1.35 to $3.67 \mathrm{~kg} / \mathrm{d}$, partly due to a reduction in dry matter (DM) digestibility from 0.77 to 0.58 and partly to an increase in faecal moisture from 0.76 to $0.84 \mathrm{~g} / \mathrm{g}(P<0.01)$.

Effects of the digestion of energy. Fermentation was suppressed dramatically by antibiotics, as indicated by a large decrease in energy digestion compared with that when antibiotics were not added. The difference in the energy digestion between the treatment without $(-)$ and with $(+)$ antibiotics was considered to be the true energy digested via microbial action. The apparent digestibilities of energy are summarized in Table 5. For diet $\mathrm{C}$ the energy digested via fermentation was $1.67 \mathrm{MJ} / \mathrm{d}(15.81-14.14)$ or $10.6 \%$ of the total digested energy. The effect of antibiotics was even greater for diet SBP; the estimated fermented energy was $4.71 \mathrm{MJ} / \mathrm{d}(19.34-14.63)$ or $24.4 \%$ of the total DE.

Effects on the digestion of $D M$ and $N$. The apparent digestibilities of DM and $N$ are summarized in Table 5. The apparent digestibility of DM followed the pattern of the digestion of energy, and the effect of antibiotic treatment was significant. The apparent digestibility of $\mathrm{N}$ was significantly suppressed when antibiotics were added to diet $\mathrm{C}$, but when added to diet SBP the effect was small and not significant.

Stoichiometric estimates. In Expt 3, unlike Expts 1 and 2, the rates of VFA production 
Table 5. Expt 3. The apparent digestibilities of energy, dry matter and nitrogen with $(+)$ and without $(-)$ the addition of antibiotics $(A B)$ in growing pigs given a cereal-based diet alone (C) or supplemented with $300 \mathrm{~g}$ unmolassed sugar-beet pulp (SBP)/kg*

\begin{tabular}{cccl}
\hline & Energy & Dry matter & $\mathrm{N}$ \\
\hline Diet C: -AB & 0.85 & 0.85 & 0.90 \\
$+\mathrm{AB}$ & 0.76 & 0.75 & 0.83 \\
SED (4 df) & 0.010 & 0.0102 & 0.022 \\
Statistical significance & 0.01 & 0.05 & 0.05 \\
of difference: $P<$ & & & \\
Diet SBP: - AB & 0.78 & 0.77 & 0.75 \\
$\quad+\mathrm{AB}$ & 0.59 & 0.58 & 0.73 \\
SED (4 df) & 0.010 & 0.0102 & 0.022 \\
Statistical significance & 0.01 & 0.05 & $\mathrm{NS}$ \\
of difference: $P<$ & & & \\
\hline
\end{tabular}

NS, not significant; SED, standard error of difference.

* For details of treatments, see pp. 513-514 and Table 1.

Table 6. Expt 3. Stoichiometric estimations based on the true fermented energy and the volatile fatty acid molar proportions in the digesta of growing pigs given a cereal-based diet alone $(C)$ or supplemented with $300 \mathrm{~g}$ unmolassed sugar-beet pulp $(\mathrm{SBP}) / \mathrm{kg}^{*}$

\begin{tabular}{lccc}
\hline & Diet C & Diet SBP & SBP supplement \\
\hline Methane (l/d) & $7 \cdot 44$ & 19.8 & 14.2 \\
Acetate (MJ/d) & 0.536 & 1.368 & 0.986 \\
Propionate & 0.382 & 0.937 & 0.653 \\
Butyrate & 0.356 & 1.047 & 0.784 \\
Fermented energy & 1.700 & 4.400 & 3.200 \\
DE intake (MJ/d) & 15.8 & 19.3 & 4.6 \\
Methane/DE (\%) & 1.9 & 4.01 & 12.3 \\
VFA/DE & 8.3 & 17.4 & 52.7 \\
Fermented energy/DE & 10.8 & 22.8 & 69.6 \\
\hline
\end{tabular}

DE, digestible energy.

* For details of treatments, see pp. 513-514 and Table 1.

and the production of methane were estimated from the fermented energy and the assumed molar proportions of VFA as given in Table 2. These results are summarized in Table 6. The stoichiometric estimates of methane production were $7.44 \mathrm{l} / \mathrm{d}$ for diet $\mathrm{C}$ and $19.4 \mathrm{l} / \mathrm{d}$ for diet SBP respectively, and the estimated production of methane from the supplement of SBP per se was $14.21 / \mathrm{d}$. These estimated values contrast with those directly determined in Expts 1 and 2 (see Tables 3 and 4). Estimated production of VFA and total fermented energy accounted for only 8.3 and $10.8 \%$ respectively of the total digested energy for the cereal-based control diet, and 17.4 and $22.8 \%$ of the total DE of diet SBP. For the supplement of SBP per se, calculated by difference, the respective values were $52 \cdot 7$ and $69 \cdot 6 \%$.

Expt 4 . Table 7 summarizes the measurements of the production of combustible gases in the presence of antibiotics for the last $4 \mathrm{~d}$ of the experiment. The measurements show that combustible gases were still produced in the presence of large doses of antibiotics. This 
Table 7. Expt 4. Effect of antibiotics on the production of combustible gases in growing pigs given a cereal-based diet alone $(C)$ or supplemented with $300 \mathrm{~g}$ unmolassed sugar-beet pulp $(S B P) / \mathrm{kg}^{*}$

\begin{tabular}{lcccc}
\hline \hline & \multicolumn{2}{c}{ Diet $\mathrm{C}$} & \multicolumn{2}{c}{ Diet SBP } \\
$\begin{array}{l}\text { Period after start } \\
\text { of antibiotic } \\
\text { treatment (d) }\end{array}$ & $\begin{array}{c}\text { Hydrogen } \\
\text { (1/d) }\end{array}$ & $\begin{array}{c}\text { Methane } \\
(1 / \mathrm{d})\end{array}$ & $\begin{array}{c}\text { Hydrogen } \\
(1 / \mathrm{d})\end{array}$ & $\begin{array}{c}\text { Methane } \\
(1 / \mathrm{d})\end{array}$ \\
\hline 3 & 5.56 & 0.86 & 1.48 & 0.94 \\
4 & 5.80 & nd & 1.32 & 0.70 \\
5 & 2.05 & nd & 1.63 & nd \\
6 & 2.32 & nd & 0.58 & nd \\
\hline
\end{tabular}

nd, not detected.

* For details of treatments, see pp. 513-514 and Table 1.

implies that the antibiotics did not completely suppress microbial activity. Both gases gradually diminished during antibiotic treatment, but gaseous hydrogen was predominant, with methane production falling to undetectable levels.

\section{DISCUSSION}

\section{Expts 1 and 2}

Two approaches have been used previously to assess the production of VFA resulting from fermentation in the digestive tract of the pig. Imoto \& Namioka (1978) used a short-term in vitro fermentation system. The production of VFA was determined by incubating representative samples from the large intestine in anaerobic flasks for a known period. This method, which was essentially the same as that described by Farrell \& Johnson (1972), suffers from the following main criticisms: (1) a constant production rate of VFA is not possible; (2) accumulation of VFA occurs in the flask which depresses microbial activities and, thus, the rate of VFA production. The other method, used by Rérat et al. (1987), involved simultaneous measurements of portal blood flow rate and of the concentrations of VFA in arterial blood and the portal vein (Rérat, 1985). The daily production of VFA was then assessed by multiplying the arterio-venous difference in VFA concentrations by the blood flow rate. Apart from technical difficulties this method is subject to a possible underestimation because of VFA metabolized in the gut wall.

In the present studies the production of VFA was estimated according to fermentation stoichiometry. This technique has been widely used in ruminant studies and appears to give sensible results (Orskov et al. 1968; Whitelaw et al. 1970). Stoichiometric calculations based on measurements of methane production and VFA molar proportions in Expts 1 and 2 considerably underestimated the extent of the fermentation of SBP, the estimated fermented energy of the increment of SBP being less than $16 \%$ of its determined digested energy. This would imply that up to $84 \%$ of the energy digestion of SBP was through nonfermentative degradation. Because of the high content of NSP in SBP and the absence in the porcine gastrointestinal tract of any endogenous enzymes capable of their digestion, it seems very unlikely that the stoichiometric estimate is correct. It is, therefore, suggested that the assessment of microbial fermentation based on measurements of methane and VFA molar proportions may considerably (perhaps 6-fold) underestimate the extent of fermentation in the gut of growing pigs. A major reason for this underestimation is thought 
Table 8. The effect of changing molar proportions of volatile fatty acids on the stoichiometric calculation of the total fermented energy, using sugar-beet pulp as an example

\begin{tabular}{|c|c|c|c|}
\hline $\begin{array}{c}\text { Molar } \\
\text { proportions }\end{array}$ & \multirow{2}{*}{$\begin{array}{c}\text { Methane } \\
\text { production }(1 / \mathrm{d})\end{array}$} & \multirow{2}{*}{$\begin{array}{l}\text { Total fermented } \\
\text { energy }(\mathrm{MJ} / \mathrm{d})\end{array}$} & \multirow{2}{*}{$\begin{array}{c}\text { Relative to } 1 \\
(\%)\end{array}$} \\
\hline Acetate: propionate: butyrate & & & \\
\hline 1. $0.59: 0 \cdot 23: 0 \cdot 18$ & $5 \cdot 36$ & $1 \cdot 217$ & 100 \\
\hline 2. $0 \cdot 65: 0 \cdot 20: 0 \cdot 15$ & $5 \cdot 36$ & $1 \cdot 113$ & 91.5 \\
\hline 3. $0 \cdot 70: 0 \cdot 20: 0 \cdot 10$ & $5 \cdot 36$ & 1.058 & $86 \cdot 9$ \\
\hline 4. $0 \cdot 55: 0 \cdot 35: 0 \cdot 10$ & $5 \cdot 36$ & 1.573 & $129 \cdot 2$ \\
\hline
\end{tabular}

to relate to hydrogen transfers within the fermentation system. As is well documented, hydrogen is reduced by carbon dioxide to form methane, and is also used to form propionic acid. Methane and propionate are the two major recognized hydrogen sinks in fermentation stoichiometry (Hungate, 1966; Ørskov et al. 1968). If the processes of fermentation are not completed due, for example, to a short retention time, it is likely that hydrogen in the free form will appear in substantial quantities. However, the second experiment included the measurement of both methane and hydrogen, and it was again concluded that stoichiometric calculation based on the measurement of methane plus gaseous hydrogen could greatly underestimate the extent of microbial fermentation in the gut of growing pigs. Possible reasons for the underestimation are associated with the assumptions made for the fermentation stoichiometry which were discussed by Wolin (1960), Hungate (1966), Orskov et al. (1968) and Van Soest (1982). It is not clear whether errors in these assumptions can account completely for the underestimation occurring in the previously mentioned experiments. One of these assumptions concerns the molar proportions of VFA which are affected by diet and may change with time to an unknown extent. However, as shown in Table 8 , even substantial changes in these proportions are unlikely to contribute significantly to the underestimation.

\section{Expts 3 and 4}

In assessing the results of Expt 3 it was important to ascertain how far fermentation was suppressed by the antibiotics. As judged by the production of combustible gases the suppression of fermentation by the addition of antibiotics was far from complete. However, in view of the uncertainties regarding this assessment of fermentation it seemed preferable to measure how much dietary fibre (as NSP) was still digested in the presence of antibiotics. The results are summarized in Table 9 . For diets C and SBP, 24.4 and $24.7 \%$ respectively of the total dietary fibre (as NSP) disappeared in the presence of antibiotics, suggesting that the suppression of microbial activity was substantial but not complete. For diet $\mathrm{C}$ without antibiotics the digestibility of dietary fibre was 0.61 , but with antibiotics this was reduced to 0.24 suggesting that $40 \%$ of the fermentation of dietary fibre was not suppressed. Similarly, for diet SBP, $32 \%$ was not suppressed. For the increment of unmolassed SBP the suppression was thus calculated to be $71 \%$. The true fermented energy was then assessed by adjusting for the incomplete suppression of microbial activity. This is based on the assumption that the fermentation of all organic matter was suppressed to the same extent as that of NSP. The adjusted estimates of the production of methane, VFA and fermented energy were made by dividing by $0 \cdot 6,0.68$ and 0.71 for diet C, diet SBP and the increment 
Table 9. The apparent digestibility of total non-starch polysaccharides (NSP) in the two diets and in the supplement of sugar-beet pulp $(S B P)$ given to growing pigs

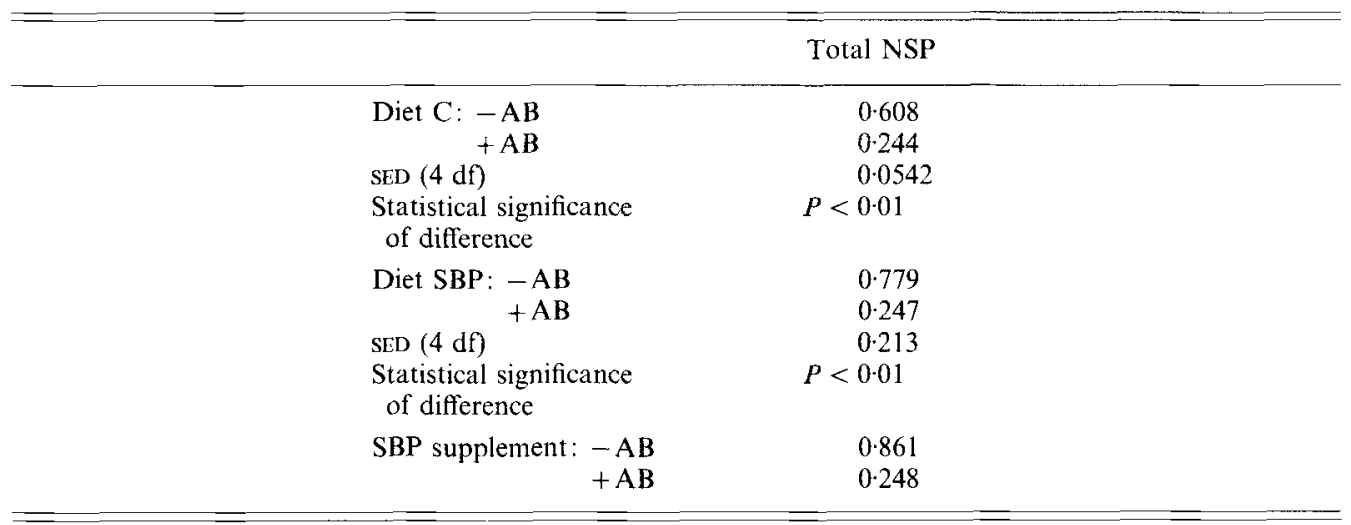

Table 10. Percentage contribution of the fermentation of sugar-beet pulp $(S B P)$ to the total digestible energy $(D E)$ of a cereal-based diet supplemented with $300 \mathrm{~g} \mathrm{SBP} / \mathrm{kg}$

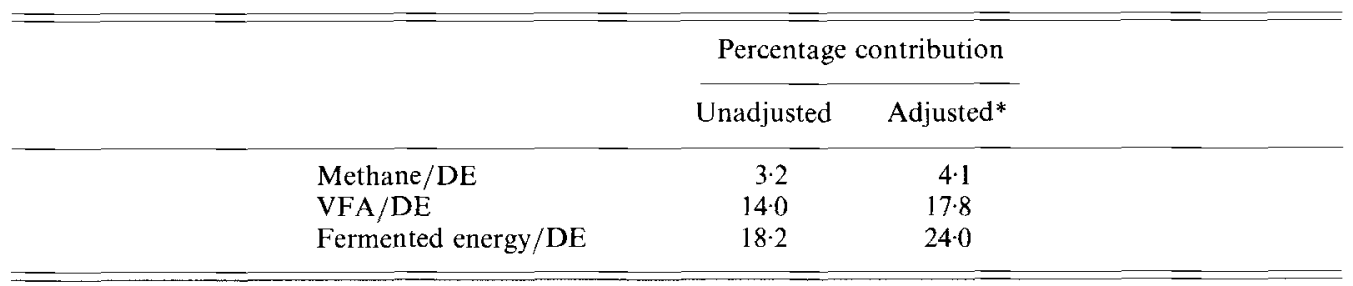

* Adjusted for incomplete suppression of fermentation by antibiotics.

of SBP respectively. These suggest that even for the cereal-based diet microbial fermentation could contribute up to $17.8 \%$ of the total DE, and with the diet incorporating $300 \mathrm{~g}$ $\mathrm{SBP} / \mathrm{kg}$ microbial fermentation could supply up to $33.4 \%$ of the total dietary DE. This calculation also indicates that $97.7 \%(69.6 \% / 71 \cdot 2 \%)$ of the digestion of the energy of the increment of SBP was via microbial action.

Table 10 shows the fractional energetic contribution from the fermentation of the supplement of SBP. The calculation involved the assumption that there were no associative effects between SBP and the diet $C$, i.e. that the DE of diet $C$ remained unchanged when it appeared in combination of the added SBP.

In Expt 4, the production of combustible gases (mainly hydrogen) was much higher in the pig given diet $\mathrm{C}$ than in that given diet SBP. This reflected the different effects of the antibiotics when administered at different doses, and was in accordance with the report of Eggum (1979) that the suppression of microbial fermentation was dependent on the dose of antibiotics used. It was also noted that hydrogen gas was produced in appreciable quantities whilst methane appeared to diminish. This suggests that the hydrogen-producing flora were more resistant to the added antibiotics than hydrogen-utilizing flora.

Comparison of two approaches to estimating fibre digestion. According to the results of Expt 3, the estimates of methane production by pigs receiving both diets appeared to be high compared with values reported in the literature (e.g. Muller \& Kirchgessner, 1986). For the increment of SBP per se the digestion of energy was mostly via fermentation $(98 \%)$. 
The estimated values for the production of methane and VFA arising from the fermentation of the supplement of SBP were 17.3 and $74 \%$ of its total digested energy. These values are in the same range as those determined in ruminants. For example, Wainman et al. (1984) found that the production of methane resulting from the fermentation of dried SBP amounted to $8 \cdot 6-19 \cdot 0 \%$ of the total fermented energy. Similar results were reported by Blaxter \& Clapperton (1965).

From a review of the recent literature, unmolassed SBP is considered to be an easilyfermentable fibre source because of its chemical composition (Low et al. 1988; Morgan \& Whittemore, 1988; Zhu et al. 1990). Calculations from the results of Expts 1 and 2 gave an estimate of its fermented energy amounting to $15.8 \%$ of its total DE, implying that $84.2 \%$ of the energy digested in SBP was by endogenous enzymes; this seems inconceivable in the light of its chemical composition. The results of Expt 3 seem to offer a more sensible estimate of the digestion of unmolassed SBP by the pig. It is, therefore, suggested that measurements of methane production, alone or with the inclusion of gaseous hydrogen, can be grossly misleading in understanding the extent of fermentation in the gut of the pig.

Stoichiometric interpretations. There are several important questions about the interpretation of fermentation stoichiometry which need to be addressed. First, why were the values of methane production measured in Expts 1 and 2 so low?

The stoichiometric method based on the measurements of methane production and VFA molar proportions appears to give sensible results in ruminants (Ørskov et al. 1968; Whitelaw et al. 1970). This was not so in our studies. One may argue that rumen fermentation stoichiometry, at least in the circumstances of these experiments, is not applicable to the fermentation in the hind-gut of the pig. However, since microbial fermentation occurring either in the rumen or in the hind-gut is thought to share virtually the same biochemical pathways (Wolin, 1974, 1981; Bayley, 1978), there is no obvious reason why it should not be valid. However, there may be some significant differences between the rumen and the pig's hind-gut in hydrogen-related biochemical processes. Some of these are discussed in the following sections. Although much of the following discussion is unavoidably speculative, it serves to indicate the relative magnitudes of various processes involved in the disposal of hydrogen in the intestine in relation to the very large discrepancy between our stoichiometric and direct estimates of hydrogen production.

Oxygen entry. In the course of fermentation hydrogen is produced and transferred in the form of reduced co-factors (e.g. $\mathrm{NADPH}_{2}, \mathrm{FADH}_{2}$ ) and hydrogen gas. These hydrogen transfer processes (see Czerkawski, 1986) are capable of releasing free energy required by microbes. In the rumen methanogenesis is always predominant whereas other processes may be more important in the hind-gut of the pig. There are major differences between the rumen and the pig hind-gut in the distribution of blood vessels and in surface area per unit volume leading to potentially large differences in oxygen diffusion from the blood into the lumen. Recent observations by Hillman et al. (1993) show that dissolved oxygen concentration in the pig intestine, including the large intestine, may reach remarkably high levels, permitting extensive aerobic microbial activity.

Reduction of sulphate and nitrate. Before sulphate can be used in microbial synthesis it must be reduced to sulphide. It is possible to make a crude estimate of the production of $\mathrm{H}_{2} \mathrm{~S}$ to illustrate this hydrogen sink quantitatively. We have no data on the composition of the gases in the intestine of pigs given diets like those used here, but if they are assumed to be similar in composition to rumen gases, with a $\mathrm{H}_{2} \mathrm{~S}$ :methane value of $3.7 \times 10^{-4}$ (Hungate, 1966) the production of $\mathrm{H}_{2} \mathrm{~S}$ can be calculated as:

$$
3.3 \times 3.7 \times 10^{-4}=1.2 \times 10^{-3}(1 / \mathrm{d}),
$$

where $3 \cdot 3$ is the production of methane from SBP per se. 
To give 1 litre $\mathrm{H}_{2} \mathrm{~S}, 4$ litres $\mathrm{H}_{2}$ are required, thus, the $\mathrm{H}_{2}$ used to produce this amount of $\mathrm{H}_{2} \mathrm{~S}$ is

$$
4 \times 1.2 \times 10^{-3}=4.8 \times 10^{-3} 1 / \mathrm{d} .
$$

This is negligible in comparison to total hydrogen production. However, Gibson et al. (1990) found that sulphate reduction in the human large intestine may play a more significant role in hydrogen disposal than methanogenesis. Its quantitative importance in the pig has yet to be established.

Nitrate is readily reduced to nitrite in fermentation. This hydrogen sink is also likely to be very small in the present experiments because there is virtually no nitrate in SBP. Although these two processes undoubtedly act as hydrogen sinks it seems likely that their magnitude is small relative to the large underestimation observed here.

Microbial synthesis of lipid and amino acids. Hydrogenation of unsaturated fatty acids occurs in gut fermentation in the pig (Mason, 1983). However, this also seems to be a small hydrogen sink because the concentrations of unsaturated fatty acids are low. According to its chemical analysis, SBP contains $8 \mathrm{~g}$ fat $/ \mathrm{kg}$ (see Table 1). Assuming this were all unsaturated oleic acid $(282 \mathrm{~g} / \mathrm{mol})$ and $1 \mathrm{~mol}$ hydrogen is required to saturate $1 \mathrm{~mol}$ oleic acid, the hydrogen used to saturate this fat would be

$$
\begin{aligned}
0.008 \times 490 / 282 & =0.014 \mathrm{~mol} \\
& =0.31 \text { litres } .
\end{aligned}
$$

The microbial lipid content is very variable, from 20 to $150 \mathrm{~g} / \mathrm{kg}$ DM (Van Soest, 1982; Czerkawski, 1986). The de novo synthesis of microbial lipids may, therefore, be an important hydrogen sink. As mentioned earlier, the intake of SBP was $490 \mathrm{~g} / \mathrm{d}$. In our previous studies (Zhu et al. 1990) we showed that the digestibility of the DM of SBP was $0 \cdot 61$. Thus, the faecal DM attributable to SBP is calculated to be $191 \mathrm{~g}(490 \times(1-0.61))$. Assuming that $70 \%$ of this is in the form of microbial mass (Mason \& Palmer, 1973), the microbial biomass would be $133 \mathrm{~g}$. If microbial DM is assumed to contain $75 \mathrm{~g}$ lipid $/ \mathrm{kg}$ the microbial DM produced in the fermentation of the SBP would be $10 \mathrm{~g} / \mathrm{d}$. Taking palmitic acid $(256 \mathrm{~g} / \mathrm{mol})$ as representative of microbial lipids then, since $14 \mathrm{~mol}$ hydrogen are required to form $1 \mathrm{~mol}$ palmitic acid, the hydrogen required would be

$$
\begin{aligned}
14 \times(10 / 256) & =0.547 \mathrm{~mol} \text { or } \\
& =12.3 \text { litres. }
\end{aligned}
$$

The sequestration of hydrogen in microbial lipid could thus be substantial.

Microbial synthesis of amino acids may also require variable amounts of reducing power, particularly the synthesis of amino acids from ammonia and carbohydrates (Nolan \& Leng, 1972; Czerkawski, 1986). Assuming that $70 \%$ of microbial DM is amino acids and assuming, as previously mentioned, that the microbial DM is $133 \mathrm{~g}$, microbial amino acid synthesis would be $93 \mathrm{~g}$. However, hydrogen sequestration in microbial substance must be set against the production of hydrogen by the degradation of SBP. If SBP is assumed to have a formula of $\mathrm{C}_{6} \mathrm{H}_{10} \mathrm{O}_{5}$ its hydrogen content is $6.2 \%$, giving a daily hydrogen input from SBP of $5.77 \mathrm{~g}$.

Assuming that $50 \%$ of the microbial amino acids are synthesized from ammonia the hydrogen input from ammonia would be $1.31 \mathrm{~g}$. Total hydrogen input from ammonia and SBP is thus calculated as $7.08 \mathrm{~g}$. The mean hydrogen content of amino acids is $7.2 \%$ so the hydrogen required in the synthesis of $93 \mathrm{~g}$ microbial amino acids is $6.70 \mathrm{~g}$. Since hydrogen in microbial lipids amounts on average to $12.5 \%$, the hydrogen required in microbial lipid synthesis is calculated as

$$
10 \times 0 \cdot 125=1 \cdot 25 \mathrm{~g} .
$$


Thus, the net output of hydrogen is calculated as

$$
6 \cdot 70+1 \cdot 25=7.95 \mathrm{~g}
$$

It can be seen that the input is only slightly lower than the output of hydrogen (7.08 v. 7.95), implying that microbial amino acid and lipid synthesis account for the disposal of only a small amount of hydrogen.

Acetogenesis. There is recent evidence suggesting that the production of acetate from hydrogen and carbon dioxide could be quantitatively significant in fermentation systems where conditions are not highly methanogenic. Lajoie et al. (1988) observed that suspensions of digesta from human subjects with relatively low concentrations of methanogens $\left(<10^{8}\right.$ per $\left.\mathrm{g} \mathrm{DM}\right)$ produced both methane and acetate from hydrogen and labelled carbon dioxide. Their results show that the production of acetate from hydrogen and carbon dioxide could be a major pathway for the use of hydrogen via microbial action. Previous studies using rats led to a similar conclusion (Prins \& Lankhorst, 1977).

In relation to our present study it is conceivable that acetogenesis from hydrogen and carbon dioxide in the hind-gut of the pig could also contribute significantly to the disposal of hydrogen since the digestive physiology of the pig closely resembles that of humans. However, we have no direct information on its importance.

Although the previous discussion is speculative, it is clear that stoichiometric calculations lead to the considerable underestimation of the fermentation of SBP. This discrepancy cannot be explained by any known alternative route of hydrogen disposal, although several routes could each make a contribution and might collectively account for a large part of the discrepancy. Perhaps more important is the fact that stoichiometric calculations are based on the assumption of a strictly anaerobic microbial metabolism which may be far from valid for the intestine of the pig (Hillman et al. 1993).

Extent of fermentation. Microbial fermentation in the gut of the pig could account for as much as $23 \%$ of the total dietary DE of diet SBP or $33.4 \%$ if calculations are based on adjustment for the incomplete suppression of fermentation by antibiotics. Although these calculations involve the assumption that the effects of antibiotics on NSP fermentation applied to the remainder of the organic matter available to the bacteria, the results are similar to estimates by Rérat et al. (1987) and Just et al. (1983a,b) using other approaches. Fermentation of the cereal-based control diet contributed up to $10.8 \%$ of its total dietary DE (17.8\% with adjustment made for incomplete suppression). This seems to be higher than has generally been assumed for conventional cereal-based pig diets (Agricultural Research Council, 1981), but there is very little direct information. Nevertheless, if one considers the fermentation not only of dietary fibre but also of endogenous secretions and of starches escaping digestion by endogenous enzymes, the estimate appears plausible.

\section{REFERENCES}

Agricultural Research Council (1981). The Nutrient Requirements of Pigs. Slough: Commonwealth Agricultural Bureaux.

Åman, P. \& Hesselman, K. (1984). Analysis of starch and other main constituents of cereal grains. Swedish Joumat of Agricultural Research 14, 135-139.

Association of Official Analytical Chemists (1965), Official Methods of Analysis. 10th ed. Washington, DC: Association of Official Analytical Chemists.

Bayley, H. S. (1978). Comparative physiology of the hindgut and its nutritional significance. Journal of Animal Science 46, $1800-1802$.

Blaxter, K. L. \& Clapperton, J. L. (1965). Prediction of the amount of methane produced by ruminants. British Journal of Nutrition 19, 51 1-522.

Brockway, J. M., McDonald, J. D. \& Pullar, J. D. (1977). Calorimetric facilities at the institute and the techniques employed to measure energy metabolism. Annual Review of the Rowett Institute 48, 193-201.

Christian, K. R. (1971). Detergent method for total lignin in herbage. Field Station Records, Division of Plant Industry, CSIRO, Australia 10, 167-175. 
Czerkawski, J. W. (1986). An Introduction to Rumen Studies. Oxford, New York, Toronto, Sydney, Frankfurt: Pergamon Press.

Davidson, J., Mathieson, J. \& Boyne, A. W. (1970). The use of automation in determining nitrogen by Kjeldahl method, with final calculation by computer. Analyst 95, 181-193.

Eggum, B. O. (1979). The effect of dietary antibiotics on protein and energy metabolism in rats; possible significance of the gut microflora. Journal of the Science of Food and Agriculture 30, 177-184.

Englyst, H. N. (1981). Determination of carbohydrates and its composition in plant materials. In The Analysis of Dietary Fibre in Food, pp. 71-94 [W. P. T. James and O. Theander, editors]. New York and Basel: Marcel Dekker.

Farrell, D. J. \& Johnson, K. A. (1972). Utilization of cellulose by pigs and its effects on caecal function. Animal Production 14, 209-217.

Gibson, G. R., Cummings, J. H., Macfarlane, G. T., Allison, C., Segal, I., Vorster, H. H. \& Walker, A. R. P. (1990). Alternative pathways for hydrogen disposal during fermentation in the human colon. Gut 31, 679-683.

Hillman, K., Whyte, A. L. \& Stewart, C. (1993). Dissolved oxygen in the porcine gastrointestinal tract. Letters in Applied Microbiology (In the Press).

Hungate, R. E. (1966). The Rumen and its Microbes. London: Academic Press.

Imoto, S. \& Namioka, S. (1978). VFA production in the pig large intestine. Journal of Animal Science 47, 467-478.

Just, A., Fernandez, J. A. \& Jørgensen, H. (1983a). The net energy value of diets for growth in pigs in relation to the fermentative processes in the digestive tract and the site of absorption of the nutrients. Livestock Production Science 10, 171-186.

Just, A., Jørgensen, H. \& Fernandez, J. A. (1983b). Maintenance requirement and the net energy value of different diets for growth in pigs. Livestock Production Science 10, 487-506.

Lajoie, S. F., Bank, S., Miller, T. L. \& Wolin, M. J. (1988). Acetate production from hydrogen and $\left[{ }^{13} \mathrm{C}\right]$ carbon dioxide by the microflora of human faeces. Applied and Environmental Microbiology 54, 2723-2727.

Lawes Agricultural Trust (1984). Genstat $V$, Mark 4.04B. Harpenden, Herts: Rothamsted Experimental Station.

Levitt, M. D. (1969). Production and excretion of hydrogen in man. New England Journal of Medicine 281, 122-127.

Levitt, M. D., Bond, J. H. \& Levitt, D. G. (1981). Gastrointestinal gas. In Physiology of the Gastrointestinal Tract, pp. 1301-1316 [L. R. Johnson, editor]. New York: Raven Press.

Levitt, M. D. \& Donaldson, R. M. (1970). Use of respiratory hydrogen excretion to detect carbohydrate malabsorption. Journal of Laboratory and Clinical Medicine 75, 937-945.

Low, A. G., Partridge, I. G. \& Taylor, J. A. (1988). Effect of different types of supplementary non-starch polysaccharides on nitrogen and energy digestibility (ileal and overall) and retention in pigs. In: 5 th International Symposium on Protein Metabolism and Nutrition, Sept. 1987, Rostock, pp. 98-99.

Marthinsen, D. \& Fleming, S. E. (1982). Excretion of breath and flatus gases by humans consuming high-fibre diets. Journal of Nutrition 112, 1133-1143.

Mason, V.C. (1983). Microbial digestion in the hindgut of the pig. International Journal for Vitamin and Nutritional Research 25, 27-43.

Mason, V. C. \& Palmer, R. (1973). The influence of bacterial activity in the alimentary canal of rats on faecal nitrogen excretion. Acta Agricuiturae Scandinavica 23, 141-150.

Matheson, J. (1970). The automated estimation of chromic oxide. Proceedings of the Nutrition Society 29, 30 A.

Morgan, C. A. \& Whittemore, C. T. (1988). Dietary fibre and nitrogen excretion and retention by pigs. Animal Feed Science and Technology 19, 185-189.

Muller, H. L. \& Kirchgessner, M. (1986). Some aspects of energy utilization in pigs. Pig News and Information 7 , $419-424$.

Nolan, J. V. \& Leng, R. A. (1972). Dynamic aspects of ammonia and urea metabolism in sheep. British Journal of Nutrition 27, 177-194.

Ørskov, E. R., Flatt, W. P. \& Moe, P. W. (1968). Fermentation balance approach to estimate extent of fermentation and efficiency of volatile fatty acid formation in ruminants. Journal of Dairy Science 51, 1429-1435.

Prins, R. A. \& Lankhorst, A. (1977). Synthesis of acetate from $\mathrm{CO}_{2}$ in the caecum of some rodents. FEMS Microbiological Letters 1, 252-258.

Rérat, A. (1978). Digestion and absorption of carbohydrates and nitrogenous matter in the hindgut and the omnivorous non-ruminant animal. Journal of Animal Science 46, 1808-1837.

Rérat, A. (1985). Intestinal absorption of end products from digestion of carbohydrates and proteins in the pig. Archives of Animal Nutrition 35, 461-480.

Rérat, A., Fiszlewicz, M., Giusi, A. \& Vaugelade, P. (1987). Influence of meal frequency on postprandial variations in the production and absorption of volatile fatty acids in the digestive tract of the conscious pig. Journal of Animal Science 64, 448-456.

Uden, P., Colucci, P. E. \& Van Soest, P. J. (1980). Investigation of chromium, cerium and cobalt as markers in digesta rate of passage studies. Journal of the Science of Food and Agriculture 31, 625-632.

Van Soest, P. J. (1982). Nutritional Ecology of the Ruminant. Corvallis, Oregon: O \& B Books, Inc.

Wainman, F. W., Dewey, P. J. S. \& Brewer, A. C. (1984). Feedstuffs Evaluation Unit, Fourth Report 1984, Rowett Research Institute, p. 9. Aberdeen: Rowett Research Institute. 
Whitelaw, F. G., Hyldgaard-Jensen, J., Reid, R. S. \& Kay, M. G. (1970), Volatile fatty acid production in the rumen of cattle given an all-concentrate diet. British Journal of Nutrition 24, 179-195.

Wolin, M. J. (1960). A theoretical fermentation balance. Journal of Dairy Science 43, 1452-1459.

Wolin, M. J. (1974). Metabolic interactions among intestinal microorganisms. American Journal of Clinical Nutrition 27, 1320-1328.

Wolin, M. J. (1981). Fermentation in the rumen and the human large intestine. Science 213, 1463-1468.

Zhu, J. Q., Fowler, V. R. \& Fuller, M. F. (1990). Digestion of sugar beet pulp in young growing pigs and implications for the value of fermented energy. Animal Production 50, 531-539. 